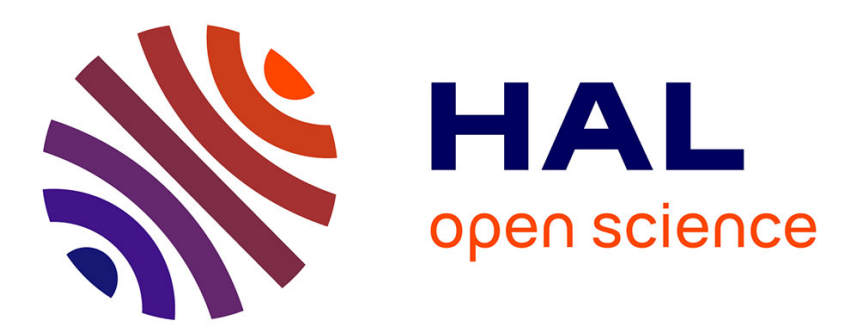

\title{
Calderas, landslides and paleo-canyons on Piton de la Fournaise volcano (La Réunion Island, Indian Ocean)
}

Olivier Merle, Philippe Mairine, Laurent Michon, Patrick Bachèlery, Magali Smietana

\section{- To cite this version:}

Olivier Merle, Philippe Mairine, Laurent Michon, Patrick Bachèlery, Magali Smietana. Calderas, landslides and paleo-canyons on Piton de la Fournaise volcano (La Réunion Island, Indian Ocean). Journal of Volcanology and Geothermal Research, 2010, 189 (1-2), pp.131-142. 10.1016/j.jvolgeores.2009.11.001 . hal-00530974

\section{HAL Id: hal-00530974 https://hal.science/hal-00530974}

Submitted on 11 Dec 2019

HAL is a multi-disciplinary open access archive for the deposit and dissemination of scientific research documents, whether they are published or not. The documents may come from teaching and research institutions in France or abroad, or from public or private research centers.
L'archive ouverte pluridisciplinaire HAL, est destinée au dépôt et à la diffusion de documents scientifiques de niveau recherche, publiés ou non, émanant des établissements d'enseignement et de recherche français ou étrangers, des laboratoires publics ou privés. 


\title{
Calderas, Landslides and Paleo-canyons on Piton de la Fournaise Volcano (La Réunion Island, Indian Ocean)
}

\author{
Olivier Merle \\ Laboratoire Magmas et Volcans UMR 6524 \\ CNRS-IRD-Université Blaise Pascal \\ 5 rue Kessler 63038 Clermont-Ferrand \\ France
}

\begin{abstract}
Philippe Mairine, Laurent Michon, Patrick Bachèlery and Magali Smietana

GéoSciences Réunion, Université de La Réunion

Institut de Physique du Globe de Paris

CNRS-UMR 7154

15 rue René Cassin 97715 Saint Denis de La Réunion
\end{abstract}

France

Corresponding author:

Olivier Merle

\begin{abstract}
Based upon a re-interpretation of previous data and a new field campaign, a structural evolution is proposed for the early history of Piton de la Fournaise volcano from 500000 to 50000 years. Conceptually, it is shown that the formation of a caldera in which lava flows are contained inside the caldera depression, gives time for erosion to excavate deep canyons on the external slopes of the volcano, for example, the Rivière des Remparts, the Rivière Langevin and the Rivière de l'Est canyons on Piton de la Fournaise volcano. These canyons are infilled when lavas, filling the caldera and overflowing its rim, are able again to flow on the external slopes of the volcano. In the past, this excavating/infilling process has occurred twice following the formation of the Rivière des Remparts and Morne Langevin calderas. The formation of the third caldera, the Plaine des Sables caldera, was followed by the excavation of the current canyons. In addition to this process, two large landslides have been documented in the field. The first, which happened about 300000 years ago, is apparently the first episode of the break up of Piton de la Fournaise volcano, predating the formation of the four large calderas. The second landslide, which occurred 150000 years ago and is considered to be less extensive, has carried away the entire southern flank of the Rivière des Remparts caldera.
\end{abstract}

Key words : Piton de la Fournaise, caldera, landslides, lava flow, paleo-canyons. 


\section{1- Introduction}

La Réunion Island is located in the Mascareignes Archipelago, off Madagascar in the Indian Ocean. Nowadays, the island is constituted of two juxtaposed volcanoes: Piton des Neiges in the west, which has been dormant for 12 ka (Deniel et al., 1992), and Piton de la Fournaise in the east (Figure 1). The latter, active for about the last $500 \mathrm{ka}$, is partly built on an older edifice, the Alizés volcano, identified by gravimetric data (Rousset et al., 1989; Malengreau et al., 1999; Gailler et al., 2009) and through drill hole data (Rançon et al., 1989), which reveal the presence of an ancient system of magma chambers beneath the Grand Brûlé area.

As with most large shield volcanoes, Piton de la Fournaise exhibits a complex volcano-tectonic evolution, difficult to unravel due to inaccessible, nearly vertical cliffs (e.g. 1000 m high in the Rivière des Remparts and the Rivière Langevin canyons) and exuberant tropical vegetation which covers the volcanic series. Even when they are visible or accessible, these volcanic series are difficult to unravel, as dates are rare and not always reliable. (McDougall, 1971; Gillot et al., 1990).

Despite these difficulties, a geological history has emerged in the 80's and 90's, making it possible to show that the long-term evolution of Piton de la Fournaise has been characterised by the formation of large calderas, several-kilometres in width, with activity shifting to the east. The most recent is the $9 \mathrm{~km}$-wide Enclos Fouque caldera, in the centre of which the active cone has been built. Predating the formation of the Enclos Fouqué caldera, three large calderas are documented, namely, from oldest to youngest: the Rivière des Remparts caldera, the Morne Langevin caldera and the Plaine des Sables caldera (Figure 2) (Bachèlery, 1981; Lénat, 1987; Chevallier and Bachèlery, 1981; Bachèlery and Mairine, 1990; Mairine and Bachèlery, 1997).

Note that these calderas have been interpreted differently by some authors who regard them as being scars of large successive landslides to the east and/or to the south-east (Duffield et al., 1982; Gillot et al., 1994; Oehler et al., 2004, 2008), with the notable exception of the Morne Langevin caldera, which is not taken into account in this interpretation. This hypothesis of eastward or south-eastward landslides, generating as it would each time a slope in this same direction, cannot be reconciled with the observation of huge lava flows through time, which overflowed the caldera rims westward and north-westward, leaving beyond very thick horizontal lava piles, up to $1000 \mathrm{~m}$ thick, like the Morne Langevin unit.

In this article, we propose a new structural evolution of the time period from $550 \mathrm{ka}$ to 40 ka, which, while confirming in general the previous scheme (Bachèlery and Mairine, 1990; 
Mairine and Bachèlery, 1997), is now refined, with new interpretation of data which had remained unclear up to now. This represents a new step forward in the understanding of the volcano-tectonic history of Piton de la Fournaise volcano, and the relationship between calderas, erosion and landslides, the three main structural processes that have shaped the morphology of the edifice and have led to its present-day structure.

This early geological history of Piton de la Fournaise is best exposed in the Rivière des Remparts, Rivière Langevin and Rivière de l'Est canyons, the latter being unfortunately almost inaccessible. Elsewhere, in the Plaine des Sables and Enclos Fouqué calderas, recent lavas entirely cover ancient deposits, preventing any direct studies on them.

\section{2- Caldera and erosion}

Following field studies conducted in the 90's (Bachèlery and Mairine, 1990; Mairine and Bachèlery, 1997), the major discovery is that an important erosional phase led to the formation of a paleo Rivière des Remparts having a course pretty close to the present-day Rivière des Remparts. The model proposed at that time, which is confirmed by this study, defined the structural role played by the caldera. The caldera rim is viewed as a barrier preventing lavas from flowing outside the depression. This in turn allows erosion to operate along the external slopes of the volcano for, as long as the lava flows filling the caldera do not overflow its rim. Periods of erosion and excavation are associated with cliff crumbling leading to the formation of debris flows and small-scale debris avalanche deposits (Bret et al., 2003), which are then covered by lavas when they overflow the caldera rim. These breccia units intercalated with lavas give important information about past erosional periods. Thus, a caldera defines the margin between the erosional zone and lavas, preventing the infill of canyons outside its depression, which are excavated by erosion for as long as the caldera serves as a receptacle for lavas.

Considering the effects of Piton de la Fournaise calderas on the Rivière des Remparts canyon, it is noteworthy that the two first ones, the Rivière des Remparts and Morne Langevin calderas, were entirely filled by lavas, which overflowed beyond their rims, whereas the third one, the Plaine des Sables caldera, was never completely filled, which meant that the Rivière des Remparts canyon was isolated from that time, enabling the present-day excavation of the deep canyon (Bachèlery and Mairine, 1990). This statement suggests that two paleo-canyons, rather than one, may have formed, then have been partially or entirely filled prior to the excavation of the present-day canyon. 


\section{2- Lava series}

For the last $550 \mathrm{ky}$, volcano-tectonic events have provided the framework for the definition of chrono-sratigraphical sequences, based on lava petrology and lava structural position with respect to the successive calderas (Bachèlery 1981; Bachèlery and Mairine, 1990). Only a few geochronological studies have contributed to the dating of the entire sequence (McDougall, 1971; Gillot et al., 1990; Staudacher and Allègre, 1993).

In defining the sequences, it is clear that the structural event prevails over the petrological description, as lava units of the same age may exhibit various textural and mineralogical compositions, rendering unclear spatial correlations, which become obvious when considering their structural position. For example, the Pintades lava unit, called this in the Rivière des Remparts canyon owing to the presence of large plagioclase phenocrysts, lacks such crystals in the Rivière Langevin canyon. A chrono-stratigraphical sequence may be defined when a caldera forms, interrupting lava flows beyond the ring fault. When lavas filling up the caldera overflow the ring fault and spread beyond, onto the older units, the basal contact of new lavas onto old ones is a major unconformity which separates two chronostratigraphical sequences. Following this basic principle, we define three main chronostratigraphical sequences between $550 \mathrm{ky}$ and $40 \mathrm{ky}$, which allows a new presentation of the succession of lava units proposed by Bachèlery and Mairine (1990). The three sequences are correlated with caldera formation as shown on figure 3.

Sequence A. The oldest series visible in the field is the Pintades lava unit, which is characterised by plagioclase-phyric basalts with 30-50 vol.\% plagioclase phenocrysts and occasional irregular cluster of plagioclase and clinopyroxene crystals representing dismantled gabbroic fragments (Albarède et al., 1997). The oldest outcrops are dated at about $530 \mathrm{ka}$ in the Rivière des Remparts and Rivière de 1'Est canyons (Gillot et al., 1990). This unit also includes differentiated rocks found between 1150 and $1250 \mathrm{~m}$ elevation in the cliff along the right bank of Rivière des Remparts. In general, rocks of this unit are more alkaline in bulk composition than other Piton de La Fournaise lavas (Albarède et al, 1997; Luais, 2004).

From 450-400 ka, according to available geochronological data (Gillot et al., 1990; Gillot, unpublished data in Luais, 2004), the Pintades lavas are overlain by the Olivine lava unit above $1300 \mathrm{~m}$ elevation in the cliff along the right bank of Rivière des Remparts. The unit is dominated by basaltic and picritic magmas with the presence of abundant olivine phenocrysts (Bachèlery and Mairine, 1990; Albarède et al., 1997). The upper lavas of this unit are dated at about $290 \mathrm{ka}$ on top of the cliff along the right bank of the Rivière des Remparts canyon (at the Nez de Bœuf peak). The Olivine lava unit constitutes the western external 
slopes of the volcano, which exhibits regular slopes dipping at about 8-9 degrees down to the coast.

It cannot be ruled out that a major event may have occurred before the emplacement of the Olivine lava unit onto the Pintades lava unit. Several authors have shown that the Pintades unit includes differentiated rocks found between 1150 and $1250 \mathrm{~m}$ elevation in the cliff along the right bank of Rivière des Remparts. In the main, rocks of this unit are more alkalic in bulk compositions than other Piton de La Fournaise lavas (Albarède et al, 1997; Luais, 2004), which may indicate that this unit belongs to the older, underlying Alizés volcano (Lénat et al., 2001).

Sequence B. The following unit, termed the Mahavel unit, can be observed along the left bank of the Rivière des Remparts canyon above the Pintades lava unit (Figure 2). The contact between the Mahavel and Pintades lava units is often marked by discontinuous debris flows. The Mahavel unit has been dated at about $219 \mathrm{ka}$ (Gillot et al., 1990), and is dominated by olivine phenocryst rich basalts, aphyric basalts and picrites. Previous structural observations and interpretations (Bachèlery and Mairine, 1990) have shown that dated outcrops correspond to lavas which have overflowed the Rivière des Remparts caldera, so that the basal lavas of the unit are not visible and cannot be dated.

The Olivine lava unit is missing along the left bank of the Rivière des Remparts, and also in the Rivière Langevin (Figure 2), which indicates a major volcano-tectonic event between sequences A and B over this area. This event must postdate the age measured on top of the right bank of the canyon (i.e. $290 \mathrm{ky}$ ).

The possibility of a unit older that the Mahavel unit, which postdates this tectonic event, and has now been almost entirely eroded (it might still be observed in a key outcrop: see "the guide of the Nez de Bœuf" section), remains a hypothesis. Due to the lack of new dating this leaves some uncertainty about the volcano-tectonic evolution from 290 ka to 219 ka.

Sequence C. The following unit, termed the Morne Langevin unit, is a thick, flat-lying series, up to $1000 \mathrm{~m}$ deep in some places, which lies on either the Mahavel unit or the Pintades unit. The Morne Langevin unit is dominated by basalts with few to common $(<10$ vol. \%) phenocrysts of clinopyroxene, olivine, Cr-spinel, and/or plagioclase, which contrasts with the picritic lavas whitch have up to 50 vol. \% of millimetre-sized olivine crystals (Albarède et al., 1997). The Morne langevin unit filled, then overflowed, the second caldera of Piton de la Fournaise volcano, that of the Morne Langevin, as can be clearly observed in the field (Figure 4a). 
The lack of the Mahavel lava unit in many places, which means that the Morne Langevin unit generally lies directly on the Pintades lava unit (Figure 2), with the intercalation of debris flows, indicates another volcano-tectonic event here allowing the definition of a second major unconformity between sequences B and C (Figures $4 b$ and $4 c$ ). The oldest lavas of this unit are dated at about $132 \mathrm{ka}$ in the Rivière de l'Est (Gillot et al., 1990). The youngest lavas are dated at about $60 \mathrm{ka}$ (Condomines in Bachèlery and Mairine, 1990) or $80 \mathrm{ka}$ (McDougall, 1971) at the Nez de Bœuf peak, $65 \mathrm{ka}$ on the Grand Coude plateau (Gillot et al., 1990) and $40 \mathrm{ka}$ in the Plaine des Remparts plateau (Condomines in Bachèlery and Mairine, 1990). The top of the Morne Langevin unit is marked by the start of the third Piton de la Fournaise caldera (i.e. the Plaine des Sables caldera).

A fourth sequence, D, may also be defined, which corresponds to the Plaine des Sables lava units which spread into the Plaine des Sables caldera (Figure 2). This sequence has never overflowed the ring fault of the caldera and lies outside the scope of this study.

\section{4- The guide to the Nez de Bœuf peak}

Right to the north-east of the Nez de Bœuf peak along the right bank of the Rivière des Remparts is a plateau (Figure 4d) that has been interpreted as a lava infill structure postdating the 1000-m high cliff of the canyon (Bachèlery and Mairine, 1990; Mairine, 2006). This plateau has been preserved from subsequent erosion, which has excavated the canyon, and is not matched on the left bank of the canyon where the very thick Morne Langevin unit lies upon the Pintades unit. This infill structure is an exceptional relic of the tectonic evolution in this area, which enables interpretation to be made about the relationship between erosion, calderas and lava flows.

A few dates from the cliff of the plateau, which vary from $60 \mathrm{ka}$ or $80 \mathrm{ka}$ on top to 175 $\mathrm{ka}$ in the lower third of the cliff (McDougall, 1971; Condomines in Bachèlery and Mairine, 1990) clearly reveal that the infill corresponds to several different lava units among which only the upper one can be attributed to the Morne Langevin unit. Moreover, the base of the infill sequence lies directly upon the Pintades unit - with an intercalated debris flow - the Olivine unit being absent here (Mairine, 2006).

Below the Nez de Bœuf peak, observation of the vertical contact between the infill sequence and the older Pintade and Olivine units displays two cliff retreats that may be interpreted as resulting from active erosion of the cliff during periods lacking lava flows (Figure 3a). In other words, the plateau shows three successive infills, the second and the third both being preceded by a period of erosion (i.e. cliff retreat). 
The structures observed in the Nez de Bœuf gives us the following constraints in the tectonic evolution of Piton de la Fournaise volcano, which are summarized in Figure 5: iInitial stripping of the Olivine unit down to the Pintades unit, followed by a first infill; iiFormation of a hinterland barrier (caldera 1) during which erosion generates the first cliff retreat; iii- Second infill; iv- Second barrier (caldera 2) coeval with the second cliff retreat; vFinal infill.

In this scenario, the Rivière des Remparts and the Morne Langevin calderas are considered to be calderas 1 and 2, respectively.

\section{5- Overall evolution}

The interpretation of the Nez de Bœuf structure, together with other field data, especially the present-day structural cross-sections (Figure 6), allows us to present an overall structural evolution in ten main steps (Figures 7 and 8), each of which is described in the subsequent sections.

1. Initial landslide (290 ka), termed the Rivière des Remparts landslides (RRL).

2. Lava flows in the slide scar that correspond to the lower level of the infill structure of the Nez de Bœuf

3. Formation of the Rivière des Remparts caldera (RRC)

4. Excavation of a first Rivière des Remparts paleo-canyon \#1 to the west of the caldera rim and lava infill inside the caldera (i.e. the Mahavel lava unit).

5. Overflowing of the RRC and infill of paleo-canyon \#1.

6 (or 7). Landslide, termed the Grand Coude landslide (GCL), resulting in the destruction of the southern part of the Rivière des Remparts caldera rim.

7 (or 6). Formation of the Morne Langevin caldera (MLC)

8. Excavation of the Rivière des Remparts paleo-canyon \#2 to the west of the caldera rim and lava infill inside the caldera (i.e. the Morne Langevin lava unit)

9. Overflow of the MLC and infill of paleo-canyon \#2.

10. Formation of the Plaine des Sables caldera (PSC) and excavation of the present-day canyons of Piton de la Fournaise volcano.

Dating of these principal events is founded on a few geochronological dates, which, when compared with each other, reveal notable uncertainties. For example, the upper levels of the Nez de Bœuf infill yield an age of about $60 \mathrm{ka}$ according to the U/Th method (Condomines in Bachèlery and Mairine, 1990) or $80 \mathrm{ka}$ according to the K/Ar method (McDougall, 1971). Despite these uncertainties, it is possible to propose a global absolute 
chronology of the successive events (Table 1). In the following section, we detail each major event to show their main characteristics.

\section{5-1 The Rivière des Remparts landslide}

Arguments. The main argument concerning the RRL is the systematic stripping of the Olivine unit over a large area going from the Rivière des Remparts to the Rivière Langevin canyons (Figure 4, b and c). The Olivine unit can only be observed above the Pintades unit to the south of Le Bloc. Up-river from Le Bloc, younger Mahavel or Morne Langevin units lie directly upon the Pintades unit wherever visible.

Stripping resulting from erosion is doubtful as canyons are linear structures that cannot strip a geological unit over a widespread area. The erosional hypothesis thus seems unrealistic. Moreover, the course of the present-day Rivière des Remparts canyon from Le Bloc to its northward termination is strongly oblique to the downslope direction of the volcano's external slopes, which suggests a structural guide in the excavation process, not only for the present-day canyon but also for the two paleo-canyons. In plan view, its curvature is very demonstrative of a structural control, especially in its u-priver course.

Landslide contour. The western limit of the RRL corresponds to the very high cliff which makes up the right bank of the Rivière des Remparts canyon, down to Le Bloc where it takes the direction of the Ravine des Grègues gully and follows it down to the coast (see below the late infill of this depression by the Morne Langevin unit). Up-river, the Nez de Bœuf infill structure would be a secondary indentation of the landslide, isolated and preserved from subsequent erosion, except for the limited cliff retreat (Figure 5).

The eastern limit of the RRL cannot be traced out with certainty since the cliff of the left bank of the Rivière Langevin canyon is not well dated. Two hypotheses may be proposed. If the stripping of the Olivine unit can be demonstrated in the cliff of the left bank of the Rivière Langevin canyon, which requires geochronological dating, the RRL could have a large eastward extension, maybe down to the ocean. In this case, the landslide may have affected the entire south-east quarter of Piton de la Fournaise volcano. Its contour could be traced out to the east from the Nez de Bœuf to the Ravine Ferdinand, which could be a relic partially excavated by late erosion (Figure 9a). According to this hypothesis, the RRL would be multi-directional to the south, south-east and east.

Conversely, if the left bank of the Rivière Langevin canyon can be shown to be the same as that of the right bank of the Rivière des Remparts canyon, with a complete succession of Pintades and Olivine units, the lateral limit of the RRL would follow this cliff. The RRL 
would be essentially directed to the south and would display in plan view a narrow and linear outline (Figure 9b). This outline may be superimposed onto a negative magnetic anomaly (Figure 4 in Gailler et al., 2009) interpreted as resulting from either successive erosional periods or large landslides to the south. Our study is in agreement with this second hypothesis.

Another line of evidence lends argument to this latter hypothesis. A huge multidirectional landslide would have left the volcano breached to the sea along its south-east quarter, channelling lava flows in this direction and preventing them from flowing in the opposite direction. This is not observed for the Mahavel and Morne Langevin units, which largely flowed to the west and south.

This second outline (Figure 9b) can be related to a mass-wasting event reconstructed from bathymetric studies (Oehler et al., 2008) in the southward submarine part of Piton de la Fournaise volcano. Three submarine deposits - the SF2, SF3 and SF5 deposit units - appear to originate on land from the narrow corridor delimited between the Rivière des Remparts and the Rivière Langevin canyons. We hypothesize that the SF2 deposit may correspond to the RRL. The larger SF1 deposit may correspond on land to an unknown ancient landslide whereas the SF3 and SF5 deposits may correlate to younger landslides, one of them being the Grand Coude landslide (see below).

\section{5-2 Lava flows in the Rivière des Remparts landslide scar}

Lavas that flowed at that time inside the RRL scar have been entirely eroded by the excavation of the three successive Rivière des Remparts canyons, or are now covered by younger Mahavel and Morne Langevin units in the eastward internal domains. Hence their geographic extent cannot be known. We hypothesize, however, that these lavas may correspond to the first infill of the Nez de Bœuf structure where they would have been preserved from later erosion (Figure 4d). Unfortunately, no geochronological dating has been done yet in these basal levels.

\section{5-3 Formation of the Rivière des Remparts caldera}

The RRC is the first caldera of the Piton de la Fournaise tectonic history. Located to the east of the present-day Rivière des Remparts canyon, which also excavates the western limit of the RRL, the RRC can only be traced out with accuracy in certain places, particulary a) in the north-east termination of the Bras Caron river, b) at the Plateau des Sources and c) at the Piton de l'îlet peak (Figure 4e). At the Roche Plate hamlet, it follows the eastern limit of the Pintades unit visible along the left bank of the Rivière des Remparts canyon. Its south- 
eastward limit is very difficult to map. The sharply defined change of slope around an arc on the Grand Coude plateau is assumed to correspond to its destroyed rim following the Grand Coude landslide (see later).

In the northern termination of the Rivière Langevin canyon, it is tempting to map it into the unusual contact, which can be observed at the south-east corner of the canyon at the junction of the eastern and southern cliffs (Figure 4f). However, this will have to be verify with geochronological dating of the southern cliff and will only be definitely confirmed if ages similar to that of the right bank of the Rivière des Remparts canyon are found. According to this hypothesis, we interpret dating at about $330 \mathrm{ka}$ of a large outcrop found in the canyon not far from the base of the southern cliff as a detachment from the upper part of that cliff.

\section{5-4 Excavation of the Rivière des Remparts paleo-canyon \#1}

By creating a barrier to lava flows, the RRC left time for erosion to excavate a first paleo-canyon following the western limit of the RRL. This excavation removed lavas that flowed in the RRL scar before the caldera formation. Relics of these lavas are believed to be preserved in the Nez de Bœuf secondary indentation of the RRL, an area where erosion is revealed by the retreat of the western cliff of the indentation (Figures $4 \mathrm{~d}$ and 5). The enlargement to the east of the paleo-canyon is associated with crumbling and partial collapses generating debris flows, which can be observed in places just above the Pintades unit. During the time that erosion cut away the rocks to the west, the caldera depression was slowly filled by the Mahavel unit.

\section{5-5 Overflowing of the Rivière des Remparts caldera}

The excavation of the paleo-canyon \#1 was interrupted when the Mahavel lava unit overflowed the RRC rim. This unit, or a structurally equivalent unit, can be seen lying upon the Pintades unit at the Plateau des Sources. From this place, it can be followed along the cliff that overhangs the Roche Plate hamlet to the east where it universally caps the Pintades unit. The Mahavel unit filled the paleo-canyon and then covered the basal unit of the Nez de Bœuf indentation. The overflowing is dated at about $219 \mathrm{ka}$ (Gillot et al., 1990).

\section{5-6 Morne Langevin caldera and Grand Coude landslide}

We discuss here two important tectonic events whose relative timing is uncertain. The MLC is the second large caldera on Piton de la Fournaise while the GCL is a landslide, 
probably catastrophic, which has carried away the RRC rim around most of its southward limit.

Morne Langevin Caldera. In the north, the trace of the MLC is superimposed on that of the RRC (Figure 8). Re-activating the RRC rim at the termination of the Bras Caron canyon, the MLC diverges from the RRC in the left bank of this canyon where it turns in the direction of the Bras de Mahavel canyon. There, its trace turns at right angles to follow the direction of the Rivière Langevin canyon. In the heart of the Rivière Langevin canyon, it turns again at right angles to rejoin the trace of the RRC.

This caldera is especially visible at the termination of the Bras Mahavel canyon (Figure 2c) as the ring fault has been cleaned out by the 1965 landslide. During this landslide an estimated volume ranging from 30 to $5010^{6} \mathrm{~m}^{3}$ of rocks was detached from the cliff and travelled downriver in a few minutes to the cliff of the Rivière des Remparts canyon, four kilometres away. The mechanical role played by the caldera rim in triggering the landslide has been shown in a recent paper (Merle et al., 2008).

Grand Coude landslide. This landslide carried away most of the southward limit of the RRC. This event is especially clear when looking at the western cliff of the Rivière Langevin canyon where the Mahavel unit abuts, along a steeply dipping plane, the younger Morne Langevin unit, which has flowed onto it and filled a foreland depression (Figure 6c). This means that the initial contact of the Mahavel unit against the caldera rim of the RRC (i.e. against the Pintades unit) has completely disappeared in this area.

The same structural arrangement can be observed on the left bank of the Mahavel canyon where the Morne Langevin unit is in contact with the Mahavel unit along a steeplydipping plane. Again, the Morne Langevin unit is downhill with respect to the Mahavel unit, revealing the disappearance of the initial contact between the Mahavel unit and the older units. Moreover, a continuous debris flow deposit can be seen at the base of the Morne Langevin unit in this area, especially at the Sources Michel locality, where the debris flow deposit becomes at least tens of meters thick. We interpret this continuous breccia deposit along the sole of the Morne Langevin unit as resulting from the GCL. This landslide has created a wide depression limited to the west by the Mahavel canyon and to the east along the left bank of the Rivière Langevin canyon.

\section{5-7 Excavation of the Rivière des Remparts paleo-canyon \#2}

The formation of the MLC created a new barrier for lava flows and allowed erosion to excavate the Rivière des Remparts paleo-canyon \#2, which followed the same course as the 
first one. This erosion removed the Mahavel unit resulting from the overflowing of the RRC. In a similar way to the previous excavation of paleo-canyon \#1, the Nez de Bœuf indentation is preserved from downward excavation but a second cliff retreat is observed (Figure 5).

The enlargement of the paleo-canyon to the east caused most lavas lying upon the Pintades unit to be eroded, which are dated at about $219 \mathrm{ka}$ and are attributed to the overflowing of the RRC. This is why, in many places, units of the next event (i.e. the Morne Langevin unit) rest directly upon the Pintades unit.

\section{5-8 Overflowing of the Morne Langevin caldera}

The excavation of paleo-canyon \#2 was interrupted when the Morne Langevin unit overflowed the MLC rim. This event was coeval with the eruption of enormous volumes of magmas, Morne Langevin lavas being stacked up to $1000 \mathrm{~m}$ thick in some places. This unit is widespread and forms a thick regional unit covering the whole area from the Rivière des Remparts to the Rivière Langevin canyons.

Lavas from the Morne Langevin unit filled the Nez de Bœuf indention up to the top, where they can be found in horizontal position at an elevation of about $2000 \mathrm{~m}$. Elsewhere, from west to east, this unit runs alongside and lies adjacent to the ancient borders of the RRL. To the south, it totally filled the wide depression resulting from the GCL. At Le Bloc, it flowed laterally down to the Ravine des Grègues gully, staying close to the border of the RRL.

\section{5-9 Excavation of the present-day Rivière des Remparts and Rivière Langevin canyons}

According to geochronology dates, the formation of the Plaine des Sables caldera ranges from 62 to $23 \mathrm{ka}$ (Gillot et al., 1990; Staudacher and Allègre, 1993). Whatever the age, the collapse of the Plaine des Sables caldera definitely isolated this study area and preserved it from lava flows, except for some minor peripheral eruptions like that of the Commerson event, which has a ${ }^{14} \mathrm{C}$ age on carbonised wood of $60 \pm 75$ AD (Bachèlery, 1981).

Starting from the southern coast, regressive erosion has excavated the present Rivière des Remparts canyon within the thick and massive Morne Langevin unit following a NorthSouth regional fault direction (Michon et al., 2007). At Le Bloc, departing from this structural guide for another one which was easier to follow, erosion turned to the west to dig the contact between the Morne Langevin unit and the ancient cliff of the RRL, following the curved trace of the old RRL. However, the erosion has left a large outcrop of the Morne Langevin unit 
stuck to the cliff of the right bank of the Rivière des Remparts canyon at a place called Ilet Ulysse (Figure 6b).

The present Rivière Langevin canyon appears to follow the eastern border of the RRL (Hypothesis 2 of the section on the RRL), or at least that of the GCL, digging into the contact between the Morne Langevin unit and the Pintades/Olivine units. In a similar way to that which can be observed in the Rivière des Remparts canyon, a wide outcrop of the Morne Langevin unit has been preserved from erosion at a place called the Grand Galet and stands against the cliff made up of the old units. Up-river, the Rivière Langevin canyon widens suddenly to the east, revealing the tectonic control exerted by the caldera rims of the RRC and the MLC.

\section{6- Eruptive centres}

The present magmatic system is rooted right below the active cone in the center of the Enclos Fouqué caldera. The superficial magma storage is assumed to be in a zone of interconnected small magma pockets together with a dike/sill system located above sea level at an estimated elevation ranging from 0 to 1000 meters (Lénat and Bachèlery, 1990) or, as suggested by Peltier et al. (2009), by a main magma reservoir rather than a network of interconnected magma pockets. The almost continuous migration of seismic events between $5 \mathrm{~km}$ bsl to the surface during the 1998 eruption indicates that the plumbing system is slightly offset to the west at depth (Battaglia et al., 2005). The current eruptive centre has taken over from a former one, situated at the eastern end of the Plaine des Sables, straddling the Enclos Fouqué caldera rim (Bachèlery and Mairine, 1990; Bachèlery and Lénat, 1993; Gailler et al., 2009).

The gravimetric map of La Réunion Island clearly shows that this former eruptive centre is much larger than the one below the active cone (Rousset et al., 1989; Lesquer, 1990; Malengreau et al., 1999; Gailler et al., 2009). There is a major positive anomaly linked to an intrusive complex whereas gravimetric data does not reveal any dense body below the active cone. This eruptive centre is also demonstrated by the presence of dunite and gabbro xenoliths in the eruptive products of the Plaine des Sables volcanic cones, by convergent dykes observed in the Rivière des Remparts canyon and by the central location of this cone with respect to the western and northern external slopes of Piton de la Fournaise volcano.

Dating the migration of the eruptive centre from the former to the active one is controversial, as no decisive arguments may be found to propose an undisputable chronology. However, gravimetric studies reveal that the former centre lasted much longer that the present 
one, which should be considered as relatively recent. The very impressive volumes of Morne Langevin lavas and their westward and southward widespread distribution in the Rivière des Remparts canyon and the Grand Coude plateau place in doubt the hypothesis that these lavas came from the present-day active cone. It is considered both too far away and too small. In this respect, the formation of the Plaine des Sables caldera (PSC) is an excellent candidate to date the migration from one centre to another. However, we cannot rule out that the migration is more recent and that the very massive Plateau des Basaltes unit may be attributed to the former eruptive centre.

\section{7- Calderas formation versus flank landslides}

Piton de la Fournaise Volcano experienced repeated formation of large caldera (Bachèlery, 1981; Bachèlery and Mairine, 1990) and flank landslides (Lénat et al., 1989; Labazuy, 1996; Oelher et al., 2004, 2008). This study emphasizes that these two processes occurred alternately with a recurrence interval of around several tens of thousand years.

The matter of the formation of huge calderas, which in the standard model would need gigantic magma chambers at depth, but not far from the surface, is not discussed in this article. It is known, however, that such shallow reservoirs at Piton de la Fournaise volcano are unlikely and have been totally excluded by current geophysical studies. This led to the proposal of another model of caldera formation for the Enclos Fouqué caldera based on the slow spreading of the underlying highly altered rocks of the hydrothermal system (Merle and Lénat, 2003; Michon and Saint Ange, 2008). Regarding the RRC, the MLC and the PSC, which display diameters greatly superior to that of the Enclos Fouque caldera, it is sensible to consider a similar model based on the deformation of the altered core of the volcano (BardeCabusson and Merle, 2007 ; Merle et al., 2009). The time needed to form this type of caldera, which results from the flow of the clay-rich altered rocks, raises the question of the balance between the subsidence rate and the infill rate. The tectonic evolution shown in the Rivière des Remparts canyon (Figures 7 and 8) suggests that the subsidence rate of such hydrothermal calderas largely exceeds the infill rate, making erosion active in external domains before overflow occurs.

Catastrophic destabilisations are responsible for the accumulation of debris avalanche fans offshore. They reveal considerable mass-wasting events, which are associated with episodes of volcanic destruction, leaving scars and amphitheatres in the field.

As calderas and scars are subsequently buried under lava flows associated with episodes of reconstruction of the edifice, and/or reworked by subsequent events (i.e. calderas 
or landslides), it may be difficult to distinguish between these two sorts of events in the field, and conclusions should be drawn with care. However, a good argument to infer flank destabilisation from field observations is the stripping of one of several units over a wide area as observed for the RRL at Piton de la Fournaise. Neither erosion, which generally occurs along linear canyons, nor calderas can result in such a striping of lava flow units.

Understanding the ultimate cause of these two common processes, and being able to recognize them without any doubt in the field, is certainly a major task in the future, since this forms the basis of debates and controversies in many large shield volcanoes (e.g. Tenerife in the Canary islands)

\section{8- Conclusion}

Six volcano-tectonic events have been recognised -two landslides and four calderastogether with four chrono-sratigraphical sequences based on lava petrology and on lava structural position with respect to the successive calderas.

The first volcano-tectonic event in the history of Piton de la Fournaise volcano, predating the formation of the four large calderas, is the Rivière des Remparts Landslide (RRL), which happened approximately $290 \mathrm{ka}$ ago. The RRL caused the stripping of the Olivine unit down to the Pintades unit and was essentially directed to the south. The Rivière des Remparts Caldera (RRC) is the first caldera in the Piton de la Fournaise tectonic history. Its limit can only be traced out with accuracy in places, but it is always east of the present-day Rivière des Remparts canyon. The second large caldera of Piton de la Fournaise is the Morne Langevin Caldera (MLC). This caldera is especially visible at the termination of the Bras Mahavel canyon where the tabular Morne Langevin lavas entirely filled up the caldera, overflowing its rim. At the same period, about 150000 years ago, the second landslide, the Grand Coude Landslide (GCL) carried away the entire southern flank of the Rivière des Remparts caldera. The GCL is considered to be less extensive than the RRL.

In the Rivière des Remparts area, we confirm that important erosional phases led to the formation of paleo-canyons which followed a course pretty close to the present-day canyon. Two have been identified. The first paleo-canyon followed the western limit of the RRL and was partly filled by the Mahavel unit lavas overflowing the RRC rim about $219 \mathrm{ka}$ ago. The second one followed the course of the first one, removing the Mahavel unit. In both cases, the formation of a caldera (respectively the RRC and the MLC), by containing lava flows inside the caldera depression, allowed erosion to excavate deep canyons on the external slopes of the volcano. The same process has generated the present-day excavation of the 
Rivière des Remparts canyon which is completely isolated from the current volcanic activity by the Plaine des Sables and Enclos Fouqué calderas.

Acknowledgments. This research has been funded by the French ANR project VOLCARISK (contract 06-CATT-013-04). Olivier Merle has benefited from a CNRS sabbatical year in Reunion Island from july 2007 to july 2008 to do field work on Piton de la Fournaise. We thank Gerardo J. Aguirre Diaz and Carles Soriano Clemente for useful reviews of the manuscript. 


\section{Références}

Albarède, F., Luais, B., Fitton, G., Semet, M., Kaminski, E., Upton, B.G.J., Bachèlery, P., Cheminée J.-L., 1997. The geochemical regimes of Piton de la Fournaise volcano (Réunion) during the last 530,000 years. Journal of Petrology 38, 171-201.

Bachèlery, P., 1981. Le Piton de la Fournaise (Ile de la Réunion). Etude volcanologique, structurale et pétrologique. $\mathrm{PhD}$ thesis, University of Clermont-Ferrand, ClermontFerrand, 215p.

Bachèlery, P., Mairine, P., 1990. Evolution volcano-structurale du Piton de la Fournaise depuis 0.53 Ma, In: Lénat, J-F., ed., Le volcanisme de la Réunion - Monographie:

Centre de Recherche en Volcanologie, Clermont-Ferrand, France, 213-242.

Bachèlery, P., Lénat, J.-F., 1993. Le Piton de la Fournaise. Mémoires de la Société Géologique France 163, 221-229.

Barde-Cabusson, S. and Merle, O. 2007. From steep-slope volcano to flat caldera floor. Geophysical Research Letter 34, L10305, doi: 10.1029/2007GL029784.

Battaglia, J., Ferrazzini, V., Staudacher, T., Aki, K., Cheminée J.-L., 2005. Pre-eruptive migration of earthquake at Piton de la Fournaise volcano (Réunion Island). Geophysical Journal International 161, 549-558.

Bret, L., Fèvre, Y., Join, J.-L., Robineau, B., Bachèlery P., 2003. Deposits related to degradation processes on Piton des Neiges volcano (Réunion Island): Overview and geological hazard. Journal of Volcanology and Geothermal Research, 123, 25- 41.

Chevallier, P., Bachèlery, P., 1981. Evolution structurale du volcan actif du Piton de la Fournaise, Ile de la Réunion (Océan indien occidental). Bulletin of Volcanology 44, 723-741.

Deniel, C., Kieffer, G., Lecointre, J., 1992. New ${ }^{230} \mathrm{Th}^{238} \mathrm{U}$ and ${ }^{14} \mathrm{C}$ age determinations from Piton des Neiges volcano, Reunion: A revised chronology for the Differentiated Series. Journal of Volcanology and Geothermal Research 51, 253-267.

Duffield, W. A., Stieltjes, L., Varet, J., 1982. Huge landslide blocks in the growth of Piton de la Fournaise, la Réunion, and Kilauea volcano, Hawaii. Journal of Volcanology and Geothermal Research 12, 147-160.

Gailler L.-S., Lénat, J.-F., Lambert, M., Levieux, G., Villeneuve, N., Froger, J.-L., 2009. Gravity structure of Piton de la Fournaise volcano and inferred mass transfer during the 2007 crisis. Journal of Volcanology and Geothermal Research 184, 41-48. 
Gillot, P.-Y., Nativel, P.E., Condomines, M., 1990. Géochronologie du Piton de la Fournaise. In: Lénat, J-F., Le volcanisme de la Réunion - Monographie: Centre de Recherche en Volcanologie, Clermont-Ferrand, France, p. 243-256.

Gillot, P.-Y., Lefèvre, J.-C., Nativel, P.-E., 1994. Model for the structural evolution of the volcanoes of Réunion Island. Earth Planetery and Science Letter 122, 291-302.

Labazuy, P., 1996. Reccurent landslides events on the submarine flank of Piton de la Fournaise volcano (Réunion Island). In McGuire W. J., Jones, A. P., and Neuberg, J., eds, Volcano Instability on the Earth and Other Planets, Geological Society of London Special Publication., 110, 293-305.

Lénat, J.-F., 1987. Structure et dynamique interne d'un volcan volcanique intraplaque : le Piton de la Fournaise (Ile de La Réunion). PhD thesis, University of Clermont-Ferrand.

Lenat, J.-F., Vincent, P., Bachèlery, P., 1989. The offshore continuation of an active basaltic volcano: Piton de la Fournaise (Reunion Island, Indian Ocean); Structural and geomorphological interpretation from sea beam mapping. Journal of Volcanology and Geothermal Research 36, 1-36.

Lénat, J.-F, Bachèlery, P., 1990. Structure et fonctionnement de la zone centrale du Piton de la Fournaise. In Lénat, J-F., ed., Le volcanisme de la Réunion - Monographie: Centre de Recherche en Volcanologie, Clermont-Ferrand, France, 257-296.

Lénat, J.-F., Gibert-Malengreau, B., Galdéano, A., 2001. A new model for the evolution of the volcanic island of Réunion (Indian Ocean). Journal of Geophysical Research 106, B5, 8645-8663.

Lesquer, A., 1990. Structure profonde de l'Ile de la Réunion d'après l'étude des anomalies gravimétriques. In Lénat, J-F., ed., Le volcanisme de la Réunion - Monographie: Centre de Recherche en Volcanologie, Clermont-Ferrand, France, 19-27.

Luais, B., 2004. Temporal changes in Nd isotopic composition of Piton de la Fournaise magmatism (Reunion Island, Indian Ocean). Geochemical Geophysical Geosystems 5, Q01008, doi:10.1029/2002GC000502.

MacDougall, I., 1971. The geochronology and evolution of the young volcanic island of Reunion, Indian Ocean. Geochemica and Cosmochimica Acta, 35, 261-288.

Mairine, P., Bachèlery, P., 1997. Major erosional period in the building of Piton de la Fournaise (Réunion Island). Comptes Rendus Académie des Sciences Paris 325, 243249.

Mairine, P., 2006. la route du volcan : découverte de la Fournaise ancienne. Publication LSTUR, 95p. 
Malengreau, B., Lénat, J.-F., Froger, J.-L., 1999. Structure of Réunion Island (Indian Ocean) inferred from the interpretation of gravity anomalies. Journal of Volcanology and Geothermal Research 88, 131-146.

Merle, O., Lénat, J-F., 2003. Hybrid collapse mechanism at Piton de la Fournaise (Reunion Island, Indian Ocean). Journal of Geophysical Research 108, 2166-2176.

Merle, O., Michon, L., Bachèlery, P., 2008. Caldera rim collapse: a hidden volcanic hazard. Journal of Volcanology and Geothermal Research 177, 525-530.

Merle, O., van Wyk de Vries B., Barde-Cabusson S., 2009. Hydrothermal calderas. Bulletin of Volcanology, doi: 10.1007/s00445-009-0314-6

Michon, L., Saint-Ange, F., Bachèlery, P., Villeneuve, N., Staudacher, T., 2007. Role of the structural inheritance of the oceanic lithosphere in the magmato-tectonic evolution of Piton de la Fournaise Volcano (La Reunion Island). Journal of Geophysical Research 112, B04205, doi:10.1029/2006JB004598.

Michon, L., Saint-Ange, F., 2008. Morphology of Piton de la Fournaise basaltic shield volcano (La Reunion Island) : characterisation and implication in the volcano evolution. Journal of Geophysical Research 113, B03203, doi:10.1029/2005JB004118.

Oehler, J.-F., Labazuy, P., Lénat, J.-F., 2004. Recurrence of major flank landslides during the last 2 Ma-history of Réunion Island. Bulletin of Volcanology 66, 585-598.

Oehler, J.-F., Lénat, J.-F., Labazuy, Ph., 2008. Growth and collapse of the Reunion Island volcanoes. Bulletin of Volcanology doi: 10.1007/s00445-007-0163-0.

Peltier, A., Bachèlery, P., Staudacher, T. 2009. Magma transport and storage at Piton de La Fournaise (La Réunion) between 1972 and 2007: A review of geophysical and geochemical data. Journal of Volcanology and Geothermal Research, doi:10.1016/j.jvolgeores.2008.12.008

Rançon, J.-P., Lerebour, P., Augé, T., 1989. The Grand Brûlé exploration drilling: new data on the deep framework of the Piton de la Fournaise volcano. Part 1: lithostratigraphic units and volcano-structural implications. Journal of Volcanology and Geothermal Research 36, 113-127.

Rousset, D., Lesquer, A., Bonneville, A., Lénat, J.-F., 1989. Complete gravity study of Piton de la Fournaise volcano, Reunion. Journal of Volcanology and Geothermal Research 36, $37-52$.

Staudacher, T., Allègre, C.J., 1993. Ages of the second caldera of Piton de la Fournaise volcano (Réunion) determined by cosmic ray produced ${ }^{3} \mathrm{He}$ and ${ }^{21} \mathrm{Ne}$. Earth Planetery and Science Letters 119, 395-404. 


\section{Figure captions}

Figure 1. Digital Elevation Model of the study area and location of the cross-sections of Figure 6. Insert : La Réunion Island with Piton des Neiges Volcano to the west and Piton de la Fournaise Volcano to the east. GG : Grand Galet, JP : Jean Petit, ML : Morne Langevin peak, RP: Roche Plate hamlet, PdSo : Plateau des Sources.

Figure 2. Simplified geological map of the study area. Added are the contours of the four successive calderas. RRC: Rivière des Remparts caldera, MLC: Morne Langevin caldera, PSC: Plaine des Sables caldera. See also the locations of cross-sections shown on Figure 6.

Figure 3. Sketch illustrating the relationships between the chrono-stratigraphical sequences (A, B and $\mathrm{C}$ ) and the successive calderas observed in the field (RRC: Rivière des Remparts caldera, MLC: Morne Langevin caldera, PSC: Plaine des Sables caldera)

Figure 4. a) View from the North-West of the Morne Langevin Caldera as it can be seen in the Bras de Mahavel after a recent landslide which has carried away the Mahavel rim unit in 1965. The tabular structure composed of thick lava flows of the Morne Langevin formation to the left corresponds to the Morne Langevin caldera infilling. The inclined lavas and volcanic products to the right are the remnant flank predating the Morne Langevin caldera formation; b) The superposition of lava units in the left bank of the Rivière des Remparts canyon reveals the absence of the Olivine unit; c) The same superposition as in b) is observed at the Le Bloc locality; d) The Nez de Bœuf infill structure (see explanation in the text); e), View from the North-East of the limit of the Rivière des Remparts Caldera in the Bras de Mahavel canyon; f) The caldera limits in the Rivière Langevin Canyon. Stars in Figure 1 indicate the locations of photos.

Figure 5. From top to bottom, sketches showing the evolutionary steps of the Nez de Bœuf lava infill structure. This evolution is shown in the same orientation as Figure $4 \mathrm{~d}$.

Figure 6. Three cross-sections showing the relationships between the calderas and lava units.

See locations in Figure 1. Light blue: Pintades unit, dark blue: Olivine unit, mauve: 
unknown unit (first infill of the Nez de Bœuf structure, see figure 2), green: Mahavel unit, Yellow: Morne Langevin unit, brown: Plateau des Basaltes unit. RRC, MLC, PSC : Rivière des Remparts, Morne Langevin and Plaine des Sables Calderas respectively. GCL : Grand Coude landslide.

Figure 7. From top to bottom, reconstruction through time along the western part of crosssection 6a (same colour as in Figure 6).

Figure 8. From top to bottom, reconstruction through time along cross-section $6 \mathrm{~b}$ (same colours as in Figure 6).

Figure 9. Contour of the Rivière des Remparts Landslide (RRL) according to hypothesis 1 (a-) and hypothesis 2 (b-) as discussed in the text. To the south, a recent landslide still well visible in the topography intersects the old one.

Table 1. Summary chart showing the timing of lava flow units and the main volcano-tectonic events from $550 \mathrm{ka}$ to $40 \mathrm{ky}$. Dating of different events are deduced from geochronological studies (Mc Dougall, 1971; Gillot et al. 1990; Condomines, unpublished data). 


\begin{tabular}{|c|c|c|c|}
\hline TIME (ky) & LAVA UNITS & SEQUENCES & EVENTS \\
\hline $400-$ & $-\frac{\text { Pintades lava unit }}{\text { Olivine lava unit }}$ & - & $----?---$ \\
\hline \multirow[t]{2}{*}{290} & & & $\begin{array}{l}\text { Rivière des Remparts } \\
\text { landslide (RRL) }\end{array}$ \\
\hline & $\begin{array}{l}\text { Basal unit at the } \\
\text { Nez de Boeuf }\end{array}$ & & $\begin{array}{l}\text { First infill at the } \\
\text { Nez de Boeuf }\end{array}$ \\
\hline 250 & & & $\begin{array}{l}\text { Rivière des Remparts } \\
\text { Caldera (RRC) }\end{array}$ \\
\hline $219-$ & $--\frac{\text { Mahavel }}{\text { lava unit }}-$ & & $\int \begin{array}{c}\text { Overflow of the RRC } \\
\text { then } \\
\text { second infill at the } \\
\text { Nez Boeuf }\end{array}$ \\
\hline 150 & & & $\begin{array}{c}\text { Morne Langevin } \\
\text { Caldera (MLC) }\end{array}$ \\
\hline $100-$ & $-\stackrel{\text { Morne Langevin }}{\text { lava unit }}$ & - & \begin{tabular}{|c} 
Grand Coude landslide (GCL) \\
Overflow of the MLC \\
then \\
third infill at the Nez Boeuf
\end{tabular} \\
\hline
\end{tabular}

TABLE 1 


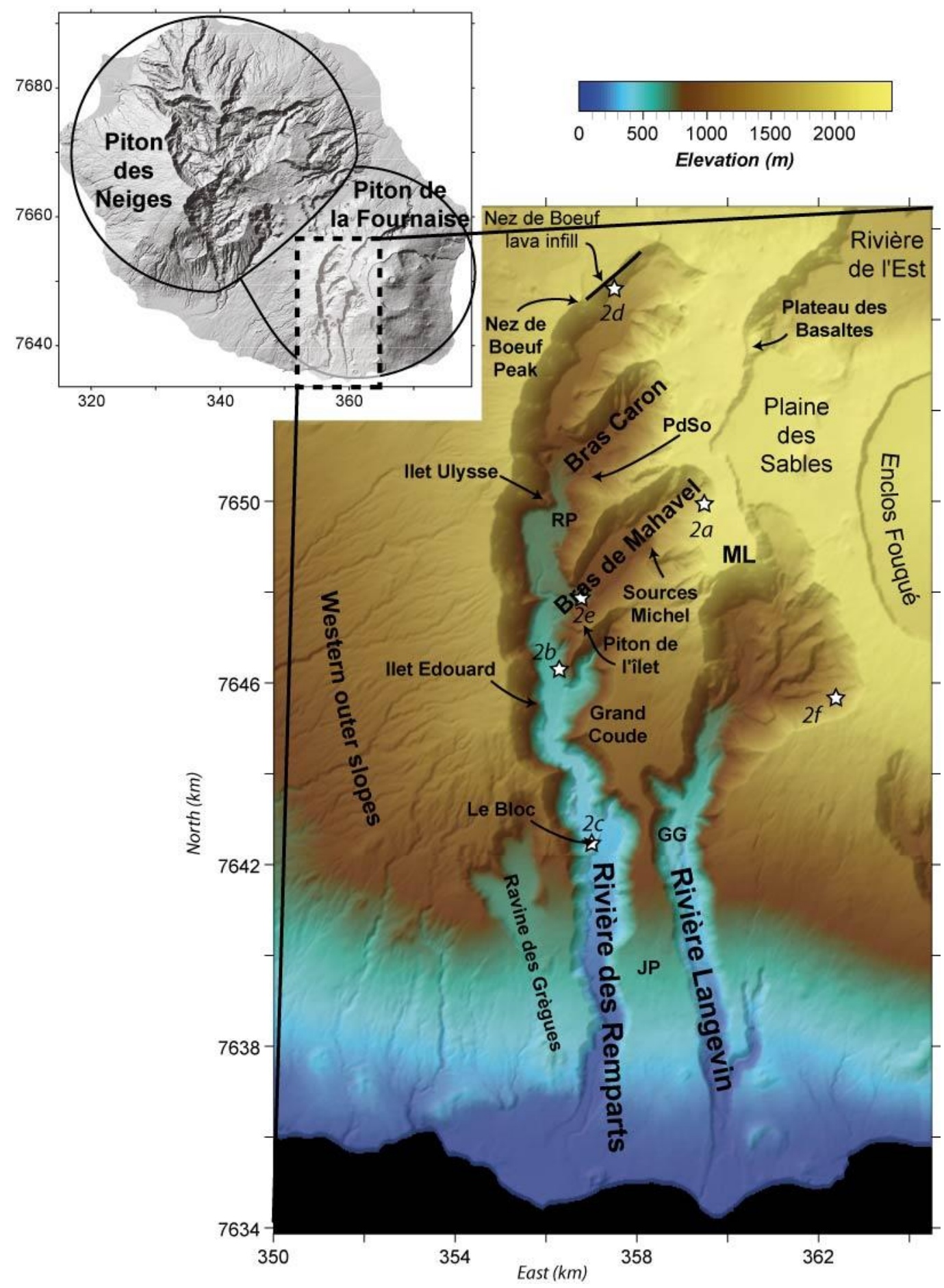

Figure 1 


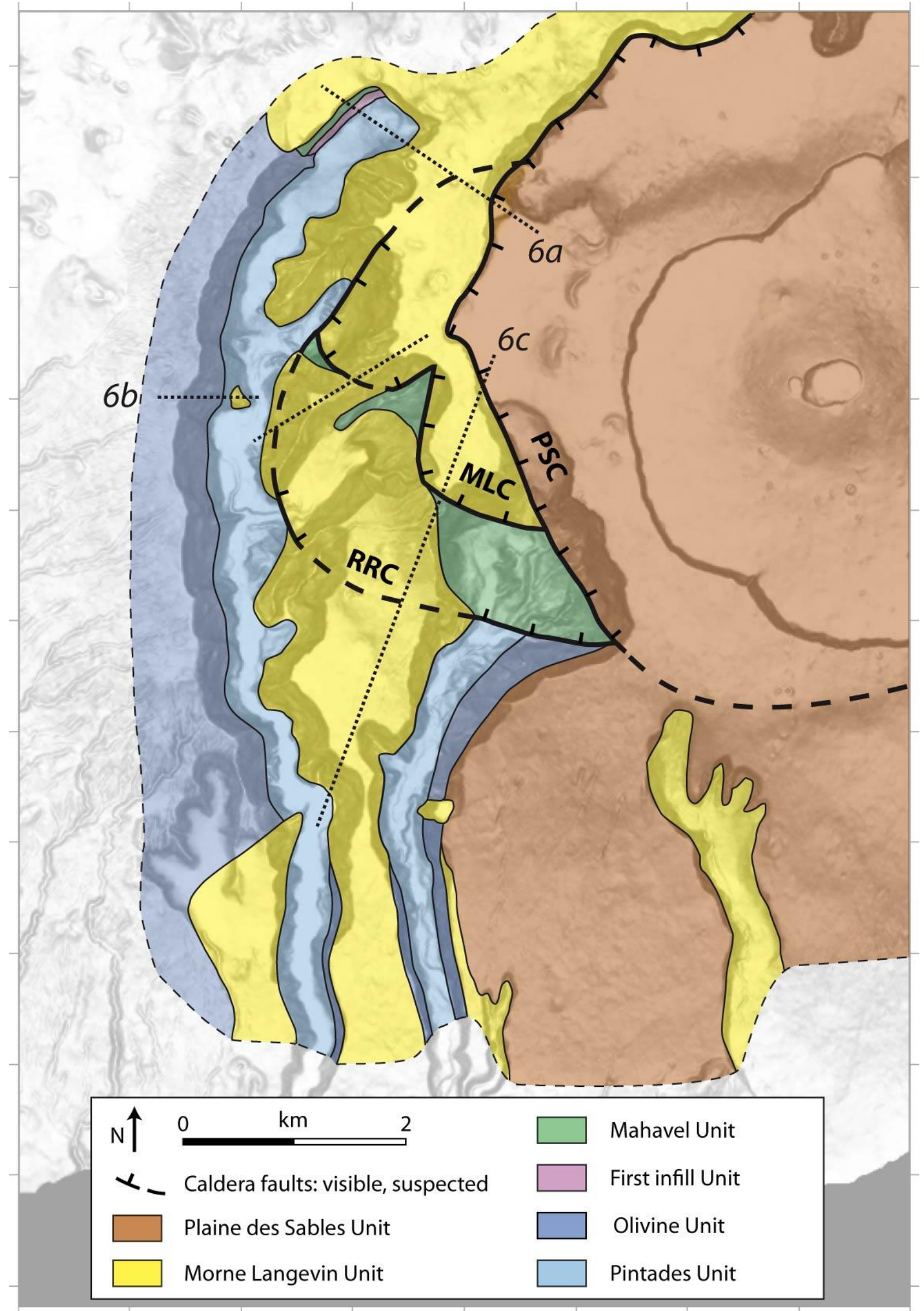

Figure 2 


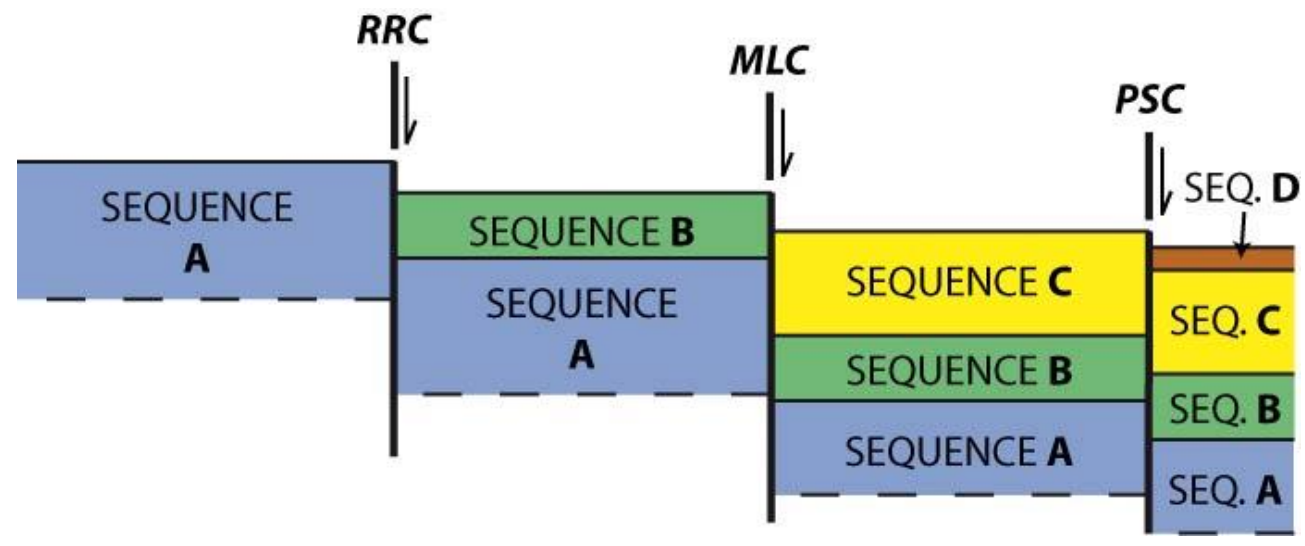

Figure 3 
a-

East

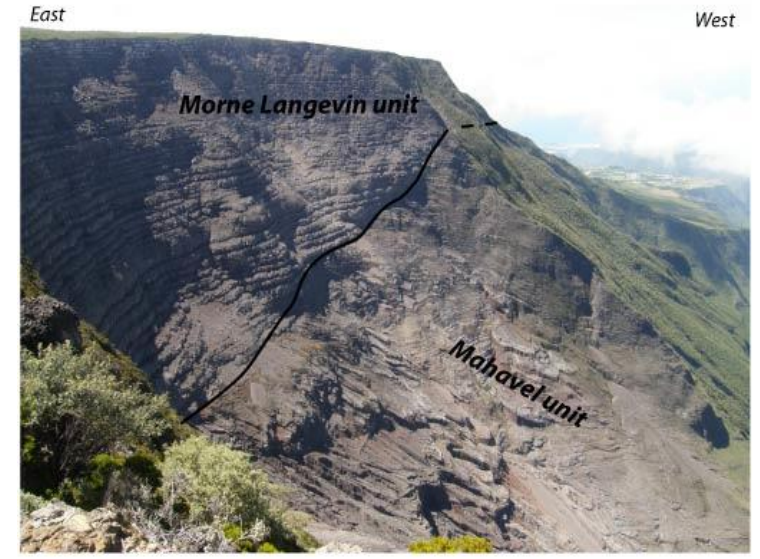

C-

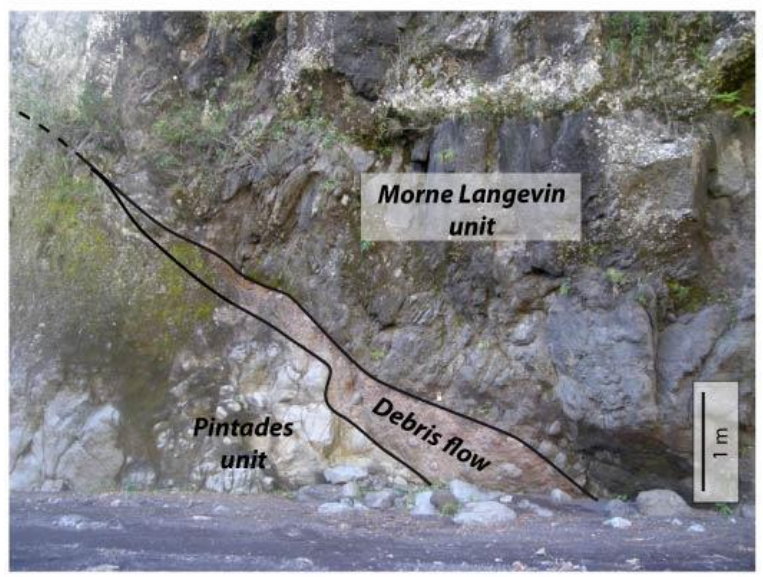

e-

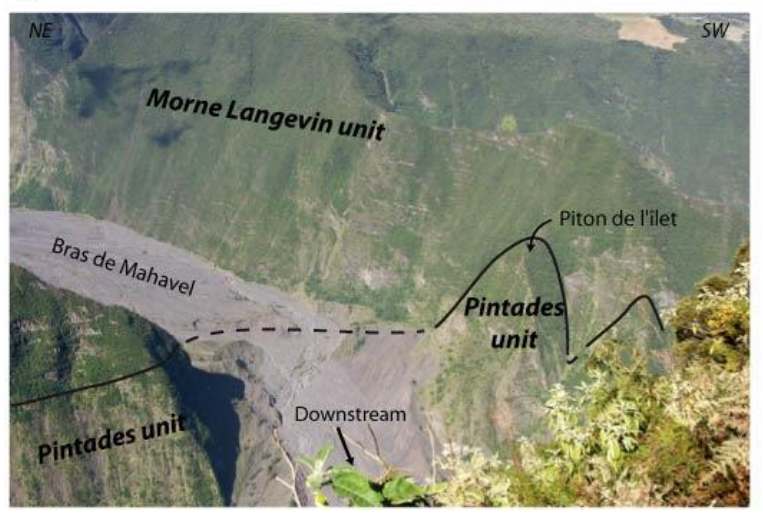

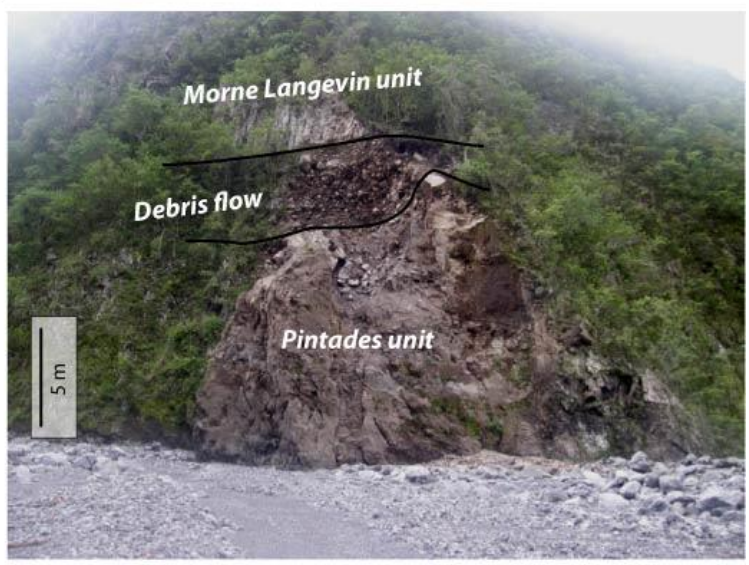

d-

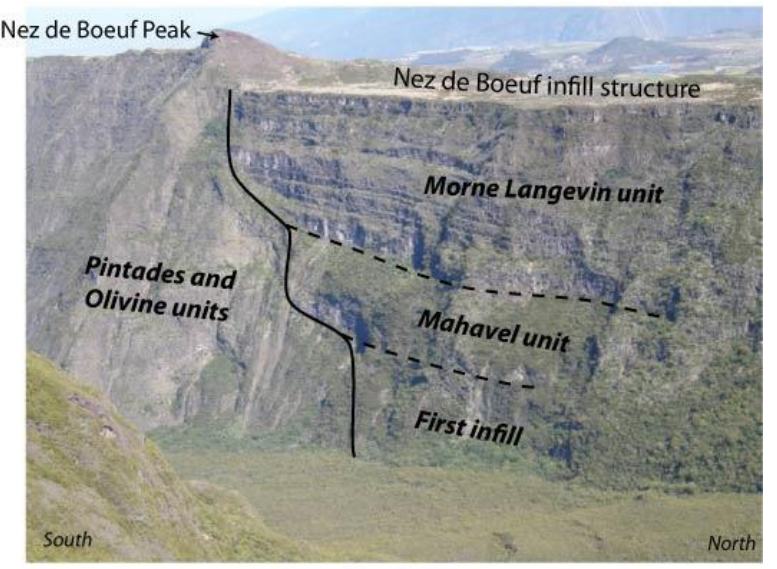

f-

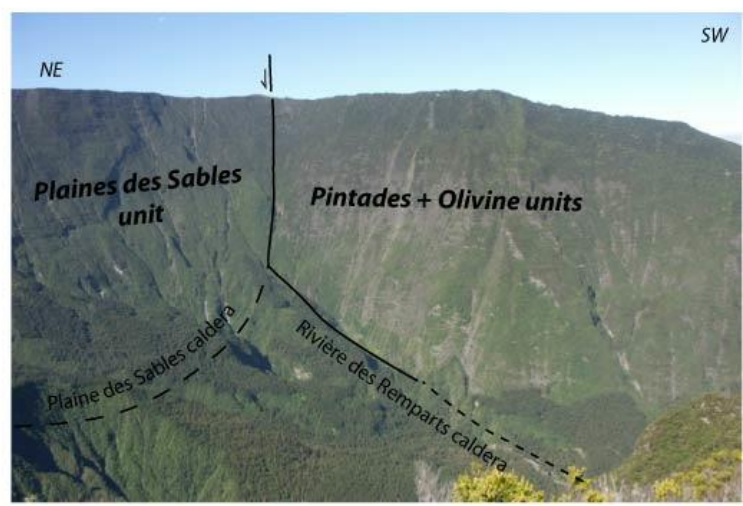

Figure 4 

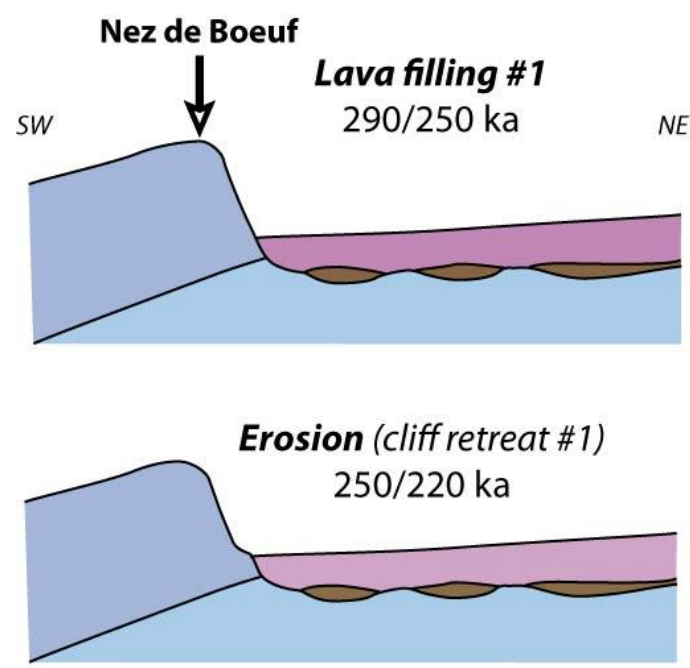

Lava filling \#2

220/150 ka

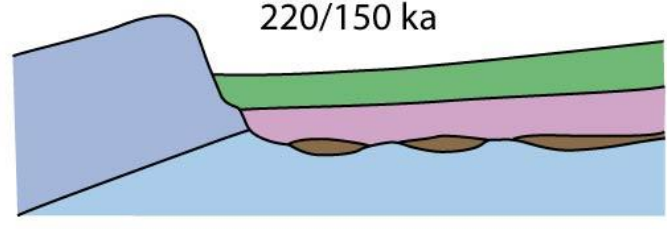

Erosion (cliff retreat \#2)

150/100 ka

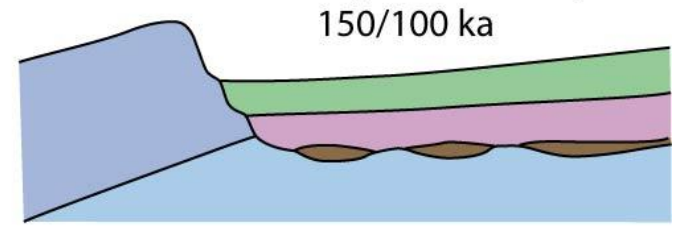

Lava filling \#3

100/60 ka

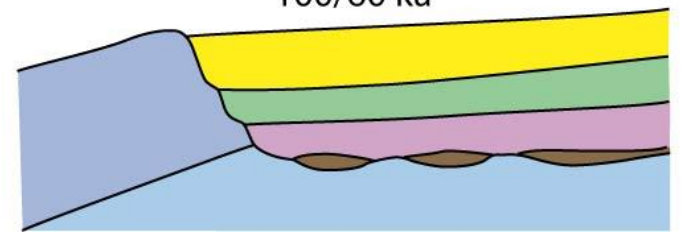

Figure 5 

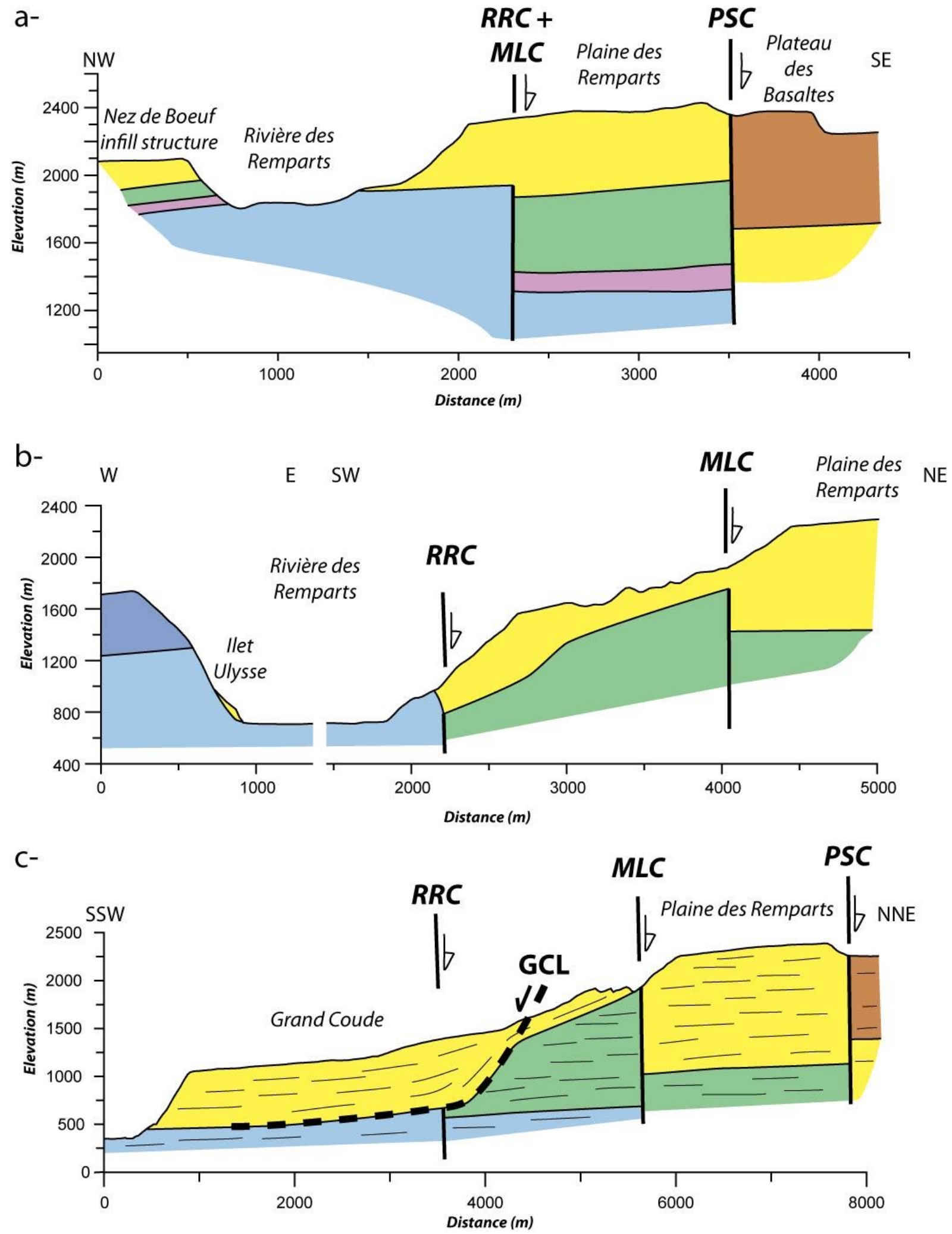

Figure 6 

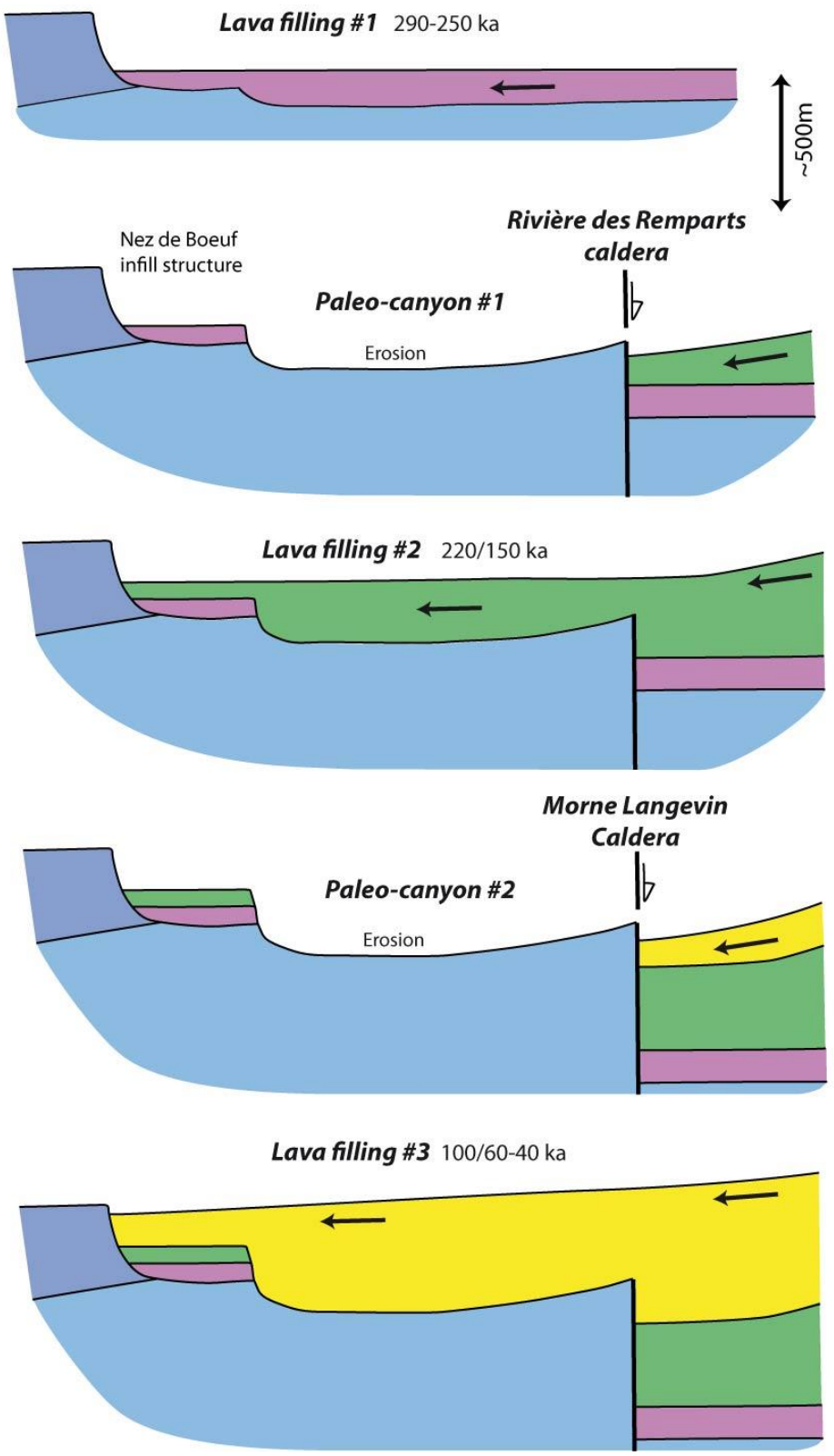

Figure 7 

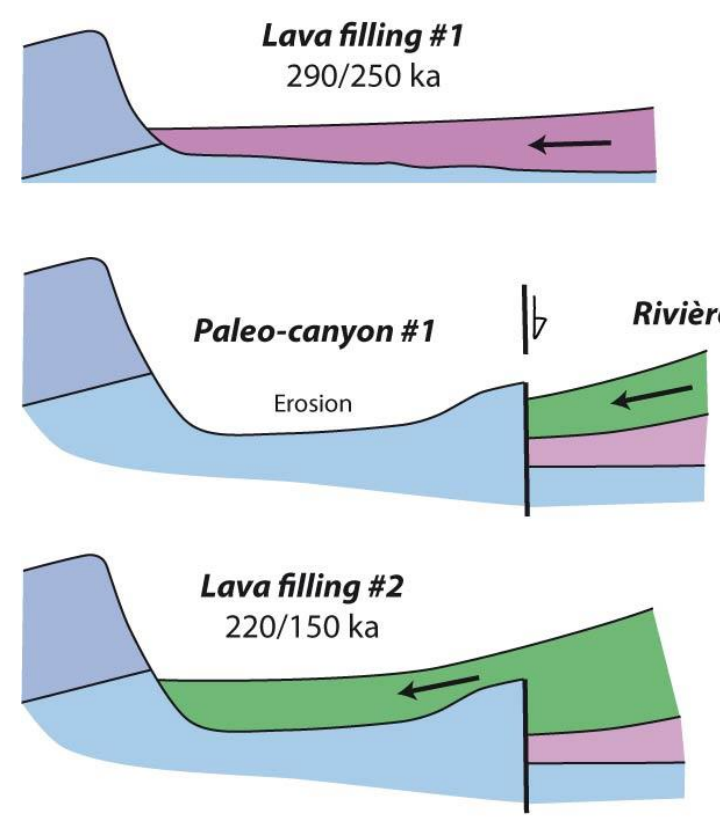

$$
\begin{aligned}
& \text { caldera } \\
& 250 \mathrm{ka}
\end{aligned}
$$
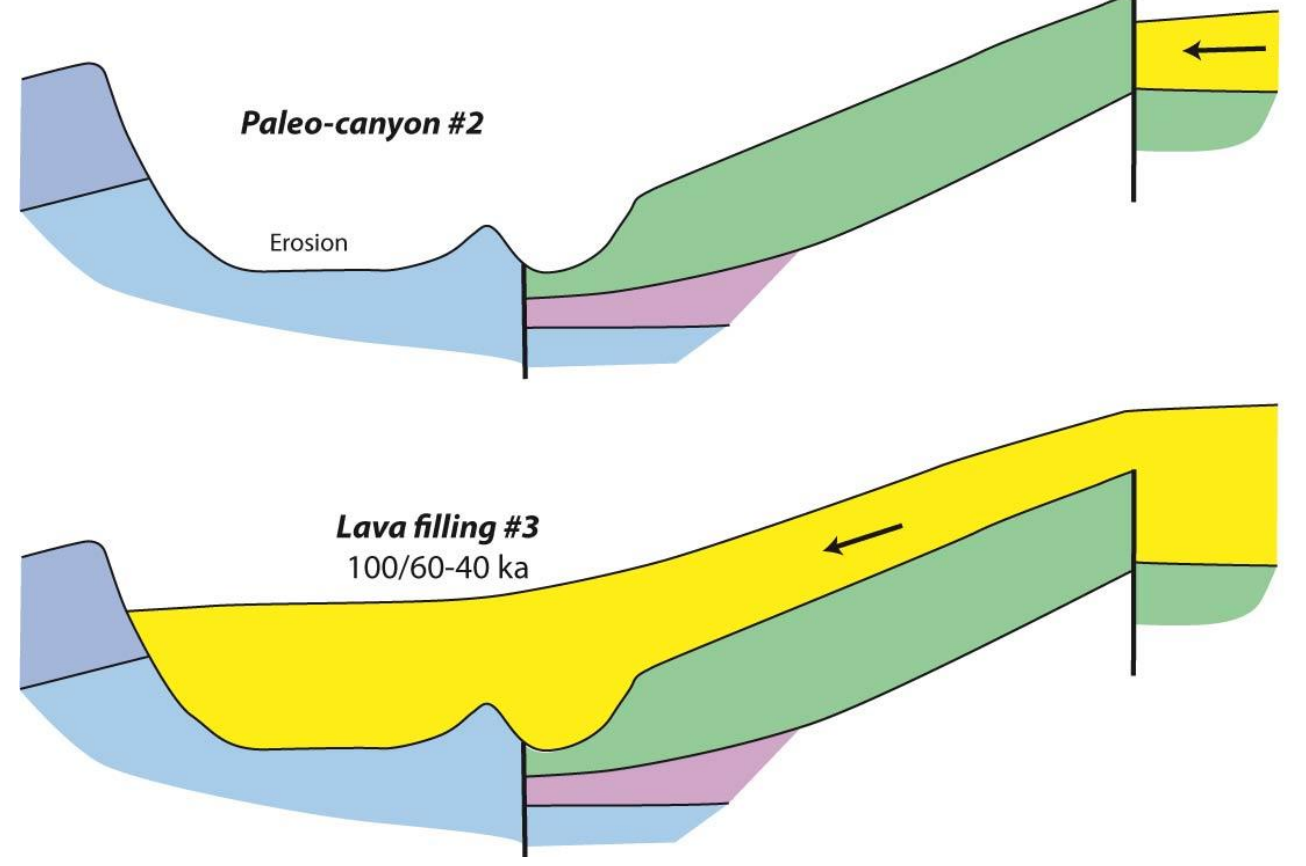

Figure 8 

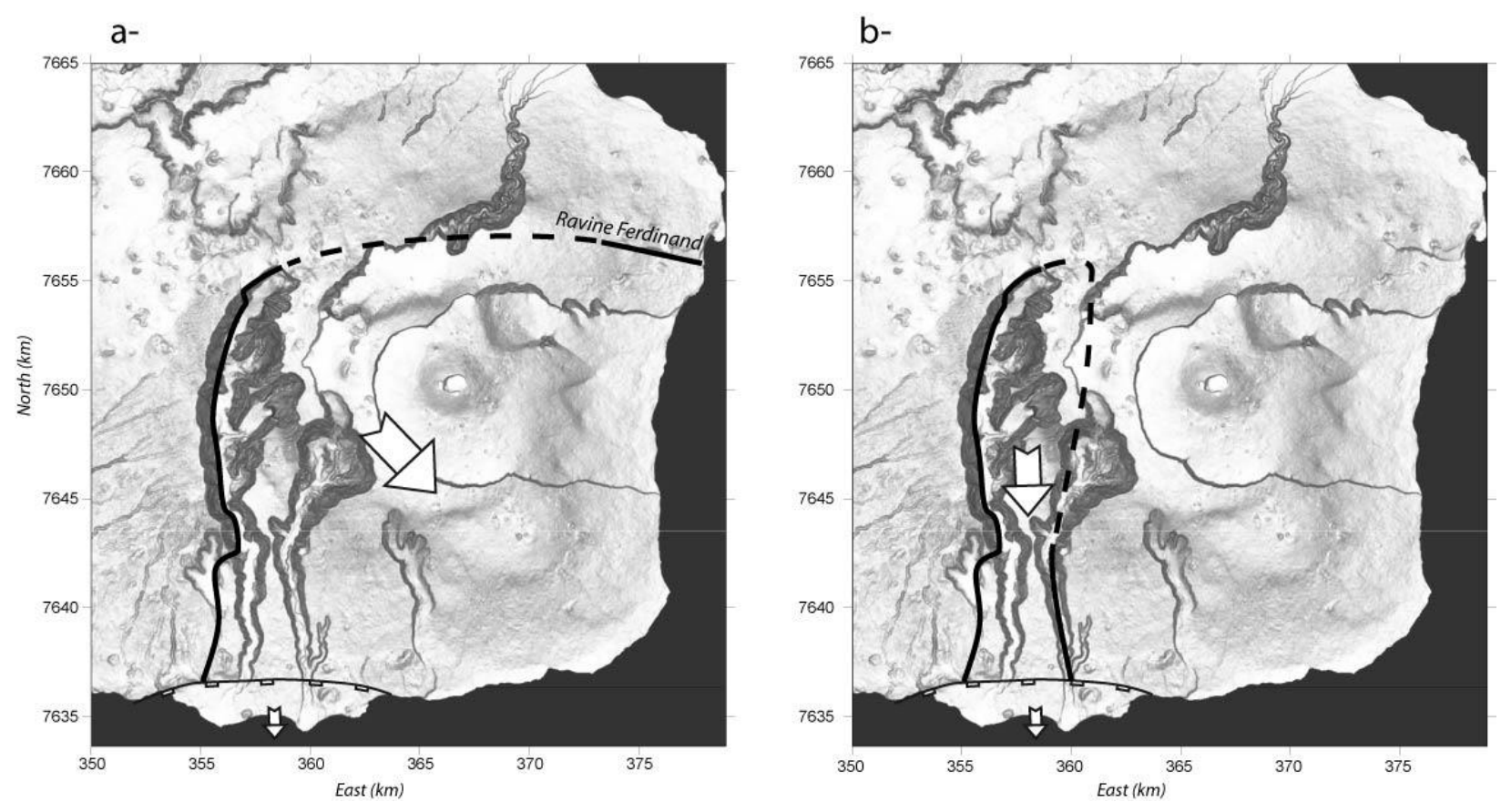

Figure 9 